\title{
SMEs Development Strategy Mode Based on Creative Economy With Quadruple Helix Approach
}

Elia Ardyan, Sekolah Tinggi Ilmu Ekonomi Surakarta, Indonesia

iD https://orcid.org/0000-0002-6705-8958

\begin{abstract}
This study aims to develop SME fashion in Central Java by quadruple helix. The statistic technique used in this research is structural equation modelling. The primary and secondary data are relevant with relating institution (SMEs). This study finds as follows: (1) test the capability sensing competitor to innovative product success, (2) test the capability of sensing competitor against entrepreneurship orientation, (3) test the capability of sensing customers towards innovative product are successful.
\end{abstract}

\section{KEYWORDS}

Competitors Sensing Capabilities, Orientation Entrepreneurship and Marketing Performance, Products Innovation Successful, Sensing Customers

\section{INTRODUCTION}

The era of the free market that has been enacted as of December 31, 2015 the member countries of ASEAN or the ASEAN Economic Community includes Indonesia, Singapore, Malaysia, Philippines, Thailand, Vietnam, Brunei, Myanmar, Cambodia and Laos. It is very advantageous to trade with a potential total population of 625 million is a lucrative market for the targeted one of the creative industries, namely clothing or fashion Muslim (Damarwulan, Mumtazah, Farida, \& Andriyansah, 2018).

Based on the data exporter Most serious Muslim dress in 2014 tops the rankings were Bangladesh amounted to USD 22 billion, ranking second is Turkey \$ 14 billion and is ranked third in Indonesia amounted to USD 11.78 billion, it can be concluded that Indonesia has the potential to develop the fashion Muslim fashion by changing the existing marketing with offline to online, in addition to increasing the exhibition and fashion show in the member countries of ASEAN Economic Community (Farida, Naryoso, \& Ardyan, 2017).

Data SMEs based on BPS in 2014 for apparel products export value experienced volatile in 2010 with the number of SMEs as much as 15678 SMEs, in 2011 increased by 17, 117 and in 2012 showed a decrease of 15.008 SMEs and in 2013 increased as much as 27.541 and in 2014 decreased by 12.246 SMEs. Factors that affect the value of apparel exports among other factors internal and external that management run still traditional, the transaction is not smooth, given the relationship between business and the buyer only based on trust, production costs based on estimates, innovation is low so tend to do imitative as well as marketing constraints (Herning I, 2016). 
Central Java is producing areas of food, beverage and textile largest in Indonesia, according to Department of Industry and Trade data of Central Java in 2014 showed that the number of Small and Medium Enterprises or SMEs apparel in 6 districts of the total of Pekalongan as many as 1041 SMEs, Kudus as many as 840 SMEs, Klaten as many as 475 SMEs, Semarang as many as 168 SMEs, Surakarta as many as 202 SMEs and Pemalang 234 SMEs (Hidayanti, Herman, \& Farida, 2018).

Problems on SMEs that Muslim fashion apparel product produced are as follows 1) it is not optimal for the market, as innovation is low and tend to be imitative and marketing constraints on products. This is due to the constraints of traditional product is still generated so that it takes fashion products with innovation and marketing of products that need to be changed based on customer requirement so that it will be able to increase marketing performance UKM.2) Research gaps between Orientation Entrepreneurship / Entrepreneurial Orientation on Marketing Performance Findings from research of Oh, Yoo, and Park (2012) shows that the entrepreneurial orientation of the influential marketing performance significantly different from the findings of the research of Zomerdijk and Voss (2009) showed that the entrepreneurial orientation does not affect the performance of marketing so there are gaps and controversies between the research results of Oh et al. (2012) Madsen et al, 2007 with the results of Gupta \& Pandit, 2012. Based on these results, the controversy formulated this study.

The purpose of this study is:

1. Testing the sensing capabilities of competitors to an innovative product successful.

2. Testing the sensing capabilities of competitors against entrepreneurship orientation.

3. Testing the sensing capabilities of customers to successful innovative products.

4. Testing the entrepreneurial orientation of the innovative products that successfully.

5. Testing successful innovative products to the performance marketing.

6. Testing the sensing capabilities of the customer to the performance marketing.

7. Testing the entrepreneurial orientation on performance marketing.

\section{LITERATURE REVIEW}

\subsection{Quadruple Helix}

In the early 1990s, the concept of Triple Helix is one of the basic concepts of the innovations developed by Henry Etzkowitz and Loet Leydesdorff which explains the need for the relationship between the university, industry and government in the development innovation (Hoffman \& Novak, 1996). In the development of the triple helix concept evolved into Quadrable helix. Quadruple helix concept developed by Elias G. Carayannis and David FJ Campbell in 2009 (See-To \& Ho, 2014). Quadruple helix concept involves civil society or the public to enter into a relationship University, government, and industry. Public within the meaning of the concept Quadruple helix is the physical environment and the social environment (Mauri \& Minazzi, 2013).

\subsection{Market Sensing Capability}

The concept of market sensing initially stated by Day (1994) in which the market sensing is one of dynamic capabilities that should be owned by the company. Market sensing capabilities are able to observe the various trends and changes taking place in the market. Teece (2007) explains that this capability is part of the dynamic capabilities that are needed in an environment that tends to change to change and uncertain. When an organization systematically and proactively learn about any changes that affect customers, competitors, and the macro environment, may gather valuable knowledge about the market and continue to see trends about current market developments and future (NA Morgan, Slotegraaf, \& Vorhies, 2009), the company will be able to produce a product or service that is better than its competitors (Fang Chang, Ou, \& Chou, 2014). And able to meet the needs of consumers both expressed and latent needs (Atuahene-Gima, Slater, \& Olson, 2005; bodlaj 2010; Bodlaj, Coenders, 
\& Zabkar, 2012; Bodlaj \& Rojsek 2010; Narver, Slater, \& Maclachlan, 2004; Tsai, Chou, \& Kuo, 2008; Voola \& O'Cass, 2010; Y. Wang, Zeng, Benedetto, \& Song, 2013).

Sensing the market is the sensing market ability is one important concept understanding, process and use information (Kok, Hillebrand, and Biemans, 2003). Market orientation based on Foley and Fahy (2004) stated upon ability sensing allows company become right market can anticipate market changes and develop upon ability to focus on new customers. Furthermore, Teece (2007) upon ability of companies to be able to continue to perform scanning, searching and browsing to the market demands upon ability to investigate customer, industry structure and new opportunities. Sensing capabilities based on J. Zhang and $\mathrm{Wu}$ (2013) is a unique capability to perform sensing opportunities by way scanning, searching by exploring the technology and market to new product development. More Roberts and Grover (2012) sensing capabilities of the consumer or customer company's ability to perform scanning, creation of learning and interpretative on consumers, and consumers an opportunity for the company to investigate the needs of customers so that the company is able to utilize the knowledge to perform sensing to customers.

\subsection{Entrepreneurship Orientation}

The concept of entrepreneurial orientation of research findings Miller (1983) shows that entrepreneurial companies can make a profit above the average through risk taking or risk taking, pro-active and always innovating. More Mochalova and Nanopoulos (2014) states that the entrepreneurial orientation can enhance an enterprise's information gathering related suppliers, competitors and customers so as to encourage dynamic capabilities of the company. Then Oh et al. (2012) research findings illustrate the time change in the entrepreneurial orientation associated with the network system of government and competencies that may be obtained in the company.

From the perspective of behavior, Covin and Slevin (1989) shows a conceptual model of EO based entrepreneurial activity, including innovative, proactive and risk-taking. Business-oriented organization will improve the behavior of EO in the form of innovative, willing to take risks and always tried to produce new products through proactive behavior to capture market opportunities (Covin \& Slevin, 1989; Wiklund \& Shepherd, 2005).

\subsection{Success Innovation Products/Innovative Product Success}

Organizations or company who want to live sustainably requires changes or novelty to keep pace with changes. Bases on Khong, Theresa, and Leong (2010) innovation generally focus on "novelty: or newness, newness has three indicators that is new in the industry, according to new consumers and new companies that have the initiative in carrying innovation (Sussman \& Siegel, 2003).

Based on Johnson (2001) the company's success in innovation, there are three: 1) framing, meaning how the interpretation companies in innovation, whereby if companies view innovation is not important will affect the company's presence and Inversely if companies view innovation is important, it will affect the company's existence, 2) Environmental innovation, a number of variables determine the success of innovation depends on a system component, the diversity, the nature of the management system, the external conditions, cultural norms of the organization toward innovation and the openness of the system organization and 3) attributes of innovation in the form of attributes based on roles subjectively of respondents play a significant role in innovation.

\subsection{Marketing Performance}

Marketing performance concept evolved over recent decades. Clark (1999) explained that there is a change in the measurement of financial performance. There are three movements, among others: first, the financial aspects (profit, sales revenue, and cash flow) to the non-financial aspects (market share, quality of service adaptability, customer satisfaction, customer loyalty, and brand equity); Second, from output to input measurement (marketing assets, marketing audit, marketing implementation, and marketing orientation); The third, from un-dimensional to multidimensional measurements) 
(efficiency, effectiveness, and multivariate analysis). Vargo and Lusch (2008) states that marketing performance includes 1) the level of sales growth, 2) market share, 3) the growing rate of profit before tax and overall performance. From a managerial standpoint, Clark (2000) explains that such marketing performance efficiency perspective, the perspective of adaptation, perspective effectiveness, and satisfaction perspective.

\section{HYPOTHESIS}

In this study, there were seven hypotheses constructed. The following hypothesis in this study is shown below.

Ardyan (2016) explains that the sensing capability of SMEs in the market will be able to increase innovation significantly. Basically, sensing the market is the company's ability to generalize the knowledge that is in the market for use in decision making (Day, 1994; Lankinen, Rökman, \& Tuominen, 2007; Olavarrieta \& Friedmann, 2008). By having the ability to sense the market, the company will be able to learn about the environment, understand the strategy of competitors, understand the market trends, and responsive. They become the knowledge gained from the outside. Alvarez and Iske (2015) explain that the source of the knowledge gained from the outside will be able to influence innovation in SMEs. Hart, Tzokas, and Saren (1999) believe that an effective market information will be able to increase the level of the company's success in innovation. Market sensing capabilities can be divided into sensing capabilities of customers and competitors sensing capability, where both will be able to increase innovation in the company.

H1: Customer Sensing Ability influence positive and significant in the success innovation products

H2: Competitor Sensing Capabilities positive and significant impact on the success of the product innovation

Some researchers explain sensing market that will be able to improve performance (Day, 1994, 2002; Tseng \& Lee, 2014). Day (2002) explains that the sensing market has the same function with the learning process. The learning process in question is the company's ability to sense, absorb and interpret information obtained from external (Day, 1994; Day \& Nedungadi, 1994). Various studies explain that the learning process will be able to increase knowledge that will ultimately affect the performance of the company (Akhtar, Arif, Rubi, and Naveed, 2011; Baker \& Sinkula, 1999; JimenezJimenez \& Sanz-Valle, 2011; Mahmud \& Hilmi, 2014; RE Morgan and Berthon, 2008). In this study, we divided the sensing capability into the sensing capabilities of customers and competitors. Both those sensing capabilities will be able to improve marketing performance.

H3: The ability of subscribers sensing positive and significant effect on marketing performance

H4: The ability of competitors sensing positive and significant effect on the performance of marketing

Basically, product innovation will be able to improve performance (Akgun, Keskin, \& Byrne, 2009; Harmancioglu, Grinstein, \& Goldman, 2010; Jenny, 2005; ZW Wang \& Wang, 2012). For created many innovations, the research and development need to be promoted, the company capabilities in innovation will impact on company performance. Companies that innovate will certainly make creating new things in the product. The current trend is that consumers want products that are up to date, the latest, and different than others. The desire of consumers of new products will make consumers vying to buy the new product. This will affect the company's performance.

H5: The success of the product innovation positive and significant effect on the performance of marketing. 
Entrepreneurial orientation is one of the important concepts in the company. Indications companies that have an entrepreneurial orientation is innovation, risk taking, and responsive. Several studies have described that entrepreneurial orientation is able to influence the innovation (Avlonitis \& Salavou, 2007). This is believed because of innovation, risk taking or responsive an entrepreneur will make him come forward and creative ideas where these ideas will be able to create something new.

H6: Entrepreneurial orientation positive and significant impact on the success of the product innovation.

Several studies have described that the entrepreneurial orientation and significant positive effect on performance (Kajalo \& Lindblom, 2015; Li, Huang, \& Tsai, 2009; Y. Zhang \& Zhang, 2012). Research conducted by Ardyan (2016) also proves that the entrepreneurial orientation still affects the performance, particularly the performance of small and medium businesses. From the point of view of the theory of competitive advantage, entrepreneurial orientation is a resource capable of facilitating the company to win the competition and generate positional advantage (Hunt, 1995; Hunt and Morgan, 1996; Hunt and Morgan, 1997). Positional excellence is what makes the company's performance to be high (Day \& Wensley, 1988). H7: entrepreneurial orientation positive and significant effect on the performance of marketing

Figure 1 shows the empirical research model developed in this study.

\section{RESEARCH METHODOLOGY}

\subsection{Sample}

The questionnaire was distributed to a sample of 350 respondents. There are as many as 294 questionnaires were returned and proper to be analyzed further, so that the sample in this study was 294 respondents. Characteristics of respondents in this study are as follows. (1) Based on gender. The majority of respondents by sex as many as 161 people or 54.8 per cent of craftsmen who have sex male and the remaining 133 people or 45.2 per cent were women. (2) Based on marital status. Based on respondents' marital status of the majority of SMEs business owners Fashion Muslim fashion has the status of a married 94.6 percent unmarried while as many as 13 people and as many as three people are already widows. (3) Based on the study. The education level of the majority of 198 votes, or 67.3 percent are educated Senior High School Level (SLTA), as many as 40 people or 13.6 per cent are educated Junior High School (SLTP), as many as 26 people or 8.8 per cent have education Diploma (D3), as many as 22 people or 7.5 percent have a Bachelor degree, and as many as 8 people or 2.7 per cent of primary school education (SD). (4) Based on the work. Based on the work of the respondents are 268 people or 91.2 per cent is as an entrepreneur or business owner Fashion Muslim clothing and as many as 21 people or 7.1 percent of private sector employees or employees is in business place, and as many as 5 people or 1.7 per cent had a job as Government employees. (5) Based on the length of the business standing. Based on the duration of the company stands 144 SME entrepreneurs Clothing or 49 percent have a long effort of 6 to 10 years, as many as 130 companies, or 44.2 per cent had a long business less than 5 years, as many as 15 companies, or 5.1 per cent had a long business 11 up to 15 years, and there are 5 or 1.7 percent of companies that have long efforts of more than 15 years. (6) Based on the status of the company. Based on the status of the company shows that the majority of SMEs business operators Fashion Clothing 273 companies or 92.9 percent of the status of the individual, as many as 19 companies or 6.5 percent CV status, and as many as two companies, or 0.7 percent of PT status. (7) Based on the number of workers. Based on the amount of power owned, the majority of respondents have about employees between 10 people of 181 companies, or 72.7 percent have fewer than 10 employees or workers, as many as 83 companies, or 33.3 percent had 11 to 30 employees or labor, as many as 18 companies 
Figure 1. Empirical Research Model

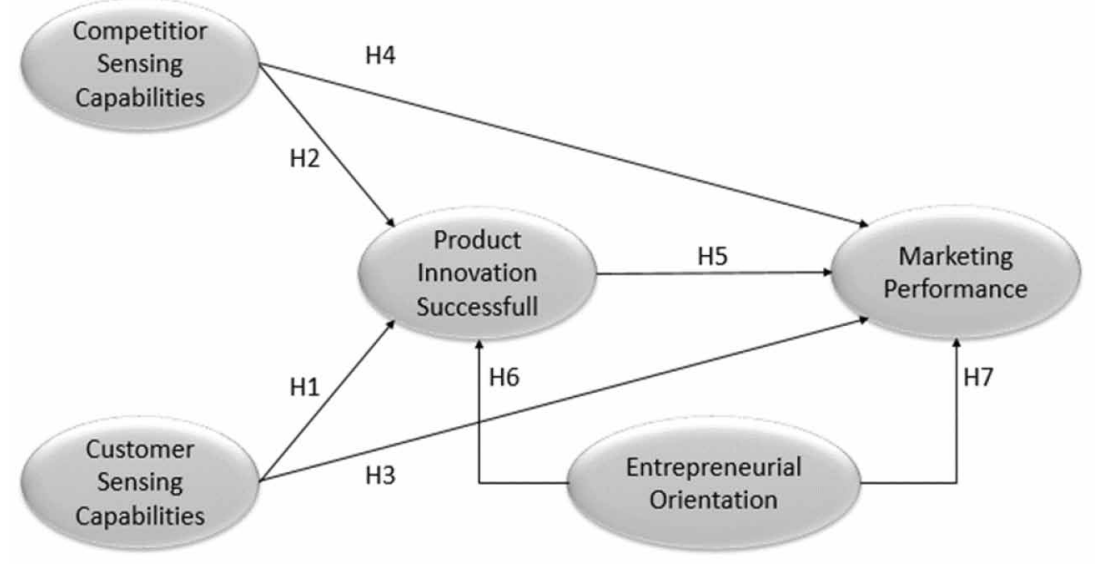

or 7.2 percent have 31 to 50 employees or labor, and 12 companies or 4.8 percent have more than 50 employees or workers.

\subsection{Measurement}

In this study there were five variables, namely the sensing capability of competitors, customer sensing capabilities, the success of product innovation, entrepreneurial orientation and marketing performance. Etc. Each item in question developed in this study measured with Likert scale, where the scale of 1 indicates is strongly disagree and 5 showing the scale of strongly agree. Operational of variables in this study are shown in Table 1.

\section{RESULTS}

\subsection{Validity and Reliability}

Reliability and validity of the instruments used to test whether the research that we've developed a reliable or valid. In this study, the measurement reliability applies Cronbach Alpha while the validity of using loading factor. Terms Cronbach Alpha is the value must be above 0.60 , the terms of validity Convergen is loading its factor value should be above 0.50 . From Table 2 we can conclude that the research instruments we have are reliable and valid. This is because both the value of factor loading and Cronbach Alpha is already above the required value.

\subsection{Goodness of Fit}

Model fit is a fit between the models is created by the research data. In this study the model of it's using IFI and CFI. IFI value is 0,806 and the CFI is 0.804 . These results are not in accordance with the prescribed cut-off value that is above 0.90 . IFI and CFI value is below 0.90, but can be tolerated because the value is still considered average.

\subsection{Results and Discussion}

There are seven proposed hypothesis proposed in this study (see Table 3). Here are the results of hypothesis testing.

The first hypothesis in this study is the ability of the customer sensing positive and significant impact on the success of the product innovation. The results of this study indicate that the customer sensing capabilities is insignificant positive effect on the success of the product innovation $(\beta=0.261$; 
Table 1. Variables and Indicators Research

\begin{tabular}{|c|c|c|c|}
\hline No. & Variable Names & Indicators & Source \\
\hline 1. & $\begin{array}{l}\text { Sensing Capability } \\
\text { Competitor }\end{array}$ & $\begin{array}{l}\text { - Ability to learn } \\
\text { - Ability to learn a competitor's product } \\
\text { - Ability to learn a competitor's product range of } \\
\text { competitor products } \\
\text { - Ability to learn a competitor's product design } \\
\text { - Strategy for understanding of the ability of } \\
\text { competitors to develop products }\end{array}$ & $\begin{array}{l}\text { Atuahene-Gima et al. } \\
\text { (2005); Narver and } \\
\text { Slater (1990); Herning } \\
\text {.I (2016) }\end{array}$ \\
\hline 2. & $\begin{array}{l}\text { Sensing Capabilities } \\
\text { Customers }\end{array}$ & $\begin{array}{l}\text { - Ability to learn future customer needs. } \\
\text { - Ability to learn the tastes of customers } \\
\text { - Ability to learn improve customer satisfaction } \\
\text { - Ability to face customer complaints and } \\
\text { suggestions } \\
\text { - The ability to understand the characteristics of } \\
\text { customers. }\end{array}$ & $\begin{array}{l}\text { Atuahene-Gima et al. } \\
\text { (2005); Narver and } \\
\text { Slater (1990); Herning } \\
\text {.I (2016) }\end{array}$ \\
\hline 3. & Success Innovation Products & $\begin{array}{l}\text { - Products novelty in the market } \\
\text { - Offer products in the market } \\
\text { - Creative } \\
\text { - Special benefits of new products } \\
\text { - Appearance of new products address the } \\
\text { troubleshooting } \\
\text { - Appearance complete new product against features } \\
\text { on the market }\end{array}$ & $\begin{array}{l}\text { J. Zhang and Wu } \\
\text { (2013); Bao, Sheng, } \\
\text { and Zhou (2012) }\end{array}$ \\
\hline 4. & Entrepreneurship Orientation & $\begin{array}{l}\text { - Risk taking } \\
\text { - Innovativeness } \\
\text { - Pro activeness }\end{array}$ & $\begin{array}{l}\text { Wiklund and Shepherd } \\
\text { (2003); Bolton, } \\
\text { Gustafsson, McColl- } \\
\text { Kennedy, Sirianni, and } \\
\text { Tse (2014) }\end{array}$ \\
\hline 5. & Performance Marketing & $\begin{array}{l}\text { - Growth in the value of sales } \\
\text { - Growth in the number of customers } \\
\text { - Gain on sale of customer retention }\end{array}$ & $\begin{array}{l}\text { Meyer and Schwager } \\
\text { (2007); Vargo and } \\
\text { Lusch (2008) }\end{array}$ \\
\hline
\end{tabular}

$\mathrm{p}=0.091$ ). Thus, hypothesis 1 is refused. Hypothesis two in this research is the ability of competitors sensing positive and significant impact on the success of the product innovation. The results of this study indicate that the sensing ability of competitors positive and significant impact on the success of the product innovation $(\beta=0.358 ; \mathrm{p}=0.014)$. So the second hypothesis is accepted.

Sensing capabilities of customers and competitors sensing capabilities have different result in influencing the success product innovation. Basically both capabilities are part of the sensing ability of the market, where the market is able to improve the sensing ability of product innovation (Ardyan, 2016; Day, 1994; Lankinen et al., 2007; Olavarrieta \& Friedmann, 2008). These results of this study indicate that in the fashion industry, especially the Muslim fashion, understand what the competition is doing (to learn a competitor's product, study the range of competitor products, study the design of competitors' products, learn the strategies of competitors) more significant effect on marketing performance compared to understand the customers (study needs customers that will come, learn the taste of customers, improve customer satisfaction, study the complaints and suggestions of customers, and understanding the characteristics of the customer). That is uniqueness in fashion business especially in the Muslim fashion.

The third hypothesis in this study is the ability of the customer sensing positive and significant effect on marketing performance. The results of this study indicate that the sensing ability of customers a significant negative effect on marketing performance $(\beta=-0.851 ; p=0.007)$. So the hypothesis 3 is rejected. Hypothesis fourth in this study is the ability of competitors sensing positive and significant 
Table 2. These Factor Loading and Cronbach Alpha

\begin{tabular}{|c|c|c|c|c|}
\hline No. & Variable Names & Indicators & $\begin{array}{c}\text { Factor } \\
\text { Loading }\end{array}$ & $\begin{array}{c}\text { Cronbach } \\
\text { Alpha }\end{array}$ \\
\hline 1. & $\begin{array}{l}\text { Sensing Capability } \\
\text { Competitor }\end{array}$ & $\begin{array}{l}\text { - Ability to learn a competitor's product (KPP1) } \\
\text { - Ability to learn a competitor's product (KPP2) } \\
\text { - Ability to learn a range of products of competitors } \\
\text { (KPP3) } \\
\text { - The ability to study the design of a competitor's } \\
\text { product (KPP4) } \\
\text { - The ability for understanding of competitors' } \\
\text { strategies in developing products (KPP5) }\end{array}$ & $\begin{array}{l}0,587 \\
0,719 \\
0.712 \\
0,664 \\
0,717\end{array}$ & 0,811 \\
\hline 2. & $\begin{array}{l}\text { Sensing Capabilities } \\
\text { Customers }\end{array}$ & $\begin{array}{l}\text { - Ability to learn needs of customers who will come } \\
\text { (PP1) } \\
\text { - Ability to learn the tastes of customers (PP2) } \\
\text { - The ability to enhance customer satisfaction (PP3) } \\
\text { - Ability to learn customer complaints and } \\
\text { suggestions (PP4) } \\
\text { - The ability to understand the characteristics of } \\
\text { customers (PP5) }\end{array}$ & $\begin{array}{l}0,676 \\
0,708 \\
0,772 \\
0,710 \\
0,707\end{array}$ & 0,836 \\
\hline 3. & $\begin{array}{l}\text { Success Innovation } \\
\text { Products }\end{array}$ & $\begin{array}{l}\text { - Products novelty in the market (KKP1) } \\
\text { - Special products in the market (KKP2) } \\
\text { - Creative (KKP3) } \\
\text { - Special benefits of the new product (KKP4) } \\
\text { - Appearance of new products address the } \\
\text { troubleshooting (KKP5) }\end{array}$ & $\begin{array}{l}0,584 \\
0,750 \\
0,559 \\
0,740 \\
0,748\end{array}$ & 0,805 \\
\hline 4. & $\begin{array}{l}\text { Entrepreneurship } \\
\text { Orientation }\end{array}$ & $\begin{array}{l}\text { - Risk taking (OK1) } \\
\text { - Innovativeness (OK2) } \\
\text { - Pro activeness (OK3) }\end{array}$ & $\begin{array}{l}0,551 \\
0,720 \\
0,659\end{array}$ & 0,674 \\
\hline 5. & $\begin{array}{l}\text { Performance } \\
\text { Marketing }\end{array}$ & $\begin{array}{l}\text { - Growth in the value of sales } \\
\text { - Growth in the number of customers } \\
\text { - Gain on sale } \\
\text { - Customer retention }\end{array}$ & $\begin{array}{l}0,848 \\
0,689 \\
0,853 \\
0,773\end{array}$ & 0,868 \\
\hline
\end{tabular}

Table 3. Results of Hypothesis Testing

\begin{tabular}{|l|l|l|}
\hline \multicolumn{1}{|c|}{ Hypothesis } & \multicolumn{1}{c|}{ Result } & \multicolumn{1}{c|}{ Notes } \\
\hline $\begin{array}{l}\text { H1: sensing capabilities customers positive and significant impact on the } \\
\text { success of product innovation }\end{array}$ & $\begin{array}{l}\beta=0,261 ; \mathrm{p}= \\
0,091\end{array}$ & Hypothesis rejected \\
\hline $\begin{array}{l}\text { H2: sensing capabilities competitors positive and significant impact on } \\
\text { the success of product innovation }\end{array}$ & $\begin{array}{l}\beta=0,358 ; \mathrm{p}= \\
0,014\end{array}$ & Hypothesis accepted \\
\hline $\begin{array}{l}\text { H3: sensing capabilities customers positive and significant effect on } \\
\text { marketing performance }\end{array}$ & $\begin{array}{l}\beta=-0,851 ; \mathrm{p}= \\
0,007\end{array}$ & Hypothesis rejected \\
\hline $\begin{array}{l}\text { H4: sensing capabilities competitors positive and significant effect on } \\
\text { the performance of marketing }\end{array}$ & $\beta=0,435 ; \mathrm{p}=0,103$ & Hypothesis rejected \\
\hline $\begin{array}{l}\text { H5: the success of the product innovation positive and significant effect } \\
\text { on marketing performance }\end{array}$ & $\beta=1,142 ; \mathrm{p}<0,05$ & Hypothesis accepted \\
\hline $\begin{array}{l}\text { H6: entrepreneurial orientation positive and significant impact on the } \\
\text { success of the product innovation }\end{array}$ & $\begin{array}{l}\beta=0,012 ; \mathrm{p}= \\
0,939\end{array}$ & Hypothesis rejected \\
\hline $\begin{array}{l}\text { H7: entrepreneurial orientation positive and significant effect on the } \\
\text { performance of marketing }\end{array}$ & $\begin{array}{l}\beta=0,743 ; \mathrm{p}= \\
0,011\end{array}$ & Hypothesis accepted \\
\hline
\end{tabular}


effect on marketing performance. The results of this study indicate that the sensing ability of the competitors but not significant positive effect on marketing performance $(\beta=0.435 ; p=0.103)$. So the hypothesis 4 was rejected.

The sense ability of customers and competitors sensing capabilities are not able to influence marketing performance positively and significantly. Basically the sensing ability of customers or competitors (sensing market) should be able to improve performance significantly (Day, 1994, 2002; Tseng \& Lee, 2014). Sensing the market (both sensing of customers or competitors sensing). Referring to the research Ardyan (2016), there are some things that cause sensing capabilities are not able to improve performance in a positive and significant, namely: the main purpose of sensing not directly improve performance but must affect innovation first.

The fifth hypothesis in this study is the successful product innovation positive and significant effect on marketing performance. The results of this study indicate that the success of the product innovation positive and significant effect on marketing performance $(\beta=1.142 ; p<0.05)$. So hypothesis 5 was accepted. The results of this study together with previous studies, in which the success of the product innovation positive and significant effect on performance (Akgun et al., 2009; Harmancioglu et al., 2010; Jenny, 2005; ZW Wang \& Wang, 2012). Business success in developing innovation will greatly affect the performance of marketing. Innovation is what will be a key driver in improving marketing performance.

The sixth hypothesis in this research is the entrepreneurship orientation positive and significant impact on the success of the product innovation. The results of this study show that entrepreneurial orientation but not significant positive effect on the success of the product keinovasian $(\beta=0.012 ; \mathrm{p}$ $=0.939$ ). So the hypothesis 6 in this study was rejected. The results of different studies with previous studies (Avlonitis \& Salavou, 2007). Referring to the results of research conducted by Ardyan (2016), which explained that there are some things that make entrepreneurial orientation are not able to have positive effect on the success innovation significant product, which is less focused on this type of innovation (incremental or radical). If the type of innovation that unexplored, then it is possibility effect will be positive and significant.

Seventh hypothesis in this research is the entrepreneurship orientation positive and significant effect on marketing performance. The results of this study show that entrepreneurial orientation and significant positive effect on marketing performance $(\beta=0.743 ; p=0.011)$. So the hypothesis 7 is received. The results are consistent with previous research studies (Ardyan, 2016; Kajalo \& Lindblom, 2015; Li et al., 2009; Y. Zhang \& Zhang, 2012). Increasingly, companies have innovation, risk-taker, and responsive to changes in the environment, it will greatly affect its performance.

\section{CONCLUSION}

Research in this study is to answer 7 research objectives outlined at the beginning. The results showed: (1) the ability of sensing customers positive effect but not significant in the success of products innovation, (2) the ability of sensing competitors positive and significant impact on the success of products innovation, (3) the ability of sensing customers a significant negative effect on marketing performance, (4) the ability of sensing competitors positive effect but not significant in marketing performance, (5) the success of product innovation positive and significant effect on marketing performance, (6) the entrepreneurship orientation positive effect but not significant in the success of products innovation, and (7) the entrepreneurship orientation positive and significant effect on marketing performance. 


\section{REFERENCES}

Akgun, A. E., Keskin, H., \& Byrne, J. (2009). Organizational emotional capability, product and process innovation, and firm performance: An empirical analysis. Journal of Engineering and Technology Management, 26(3), 103-130. doi:10.1016/j.jengtecman.2009.06.008

Akhtar, S., Arif, A., Rubi, E., \& Naveed, S. (2011). Impact of Organizational Learning on Organizational Performance: Study of Higher Education Institutes. International Journal of Academic Research, 3(5), 327-331.

Alvarez, H., \& Iske, P. (2015). Internal Capability and External Knowledge Sourcing for Product Innovation in LMT SMEs. Journal of Innovation Management, 3(2), 55-70. doi:10.24840/2183-0606_003.002_0007

Ardyan, E. (2016). Market sensing capability and SMEs performance: The mediating role of product innovativeness success. Business and Economic Review, 25(2), 1-18.

Atuahene-Gima, K., Slater, S. F., \& Olson, E. M. (2005). The Contigent Value of Responsive and Proactive Market Orientation for New Product Program Performance. Journal of Product Innovation Management, 22(6), 464-482. doi:10.1111/j.1540-5885.2005.00144.x

Avlonitis, G. J., \& Salavou, H. E. (2007). Entrepreneurial orientation of SMEs, product innovativeness, and performance. Journal of Business Research, 60(5), 566-575. doi:10.1016/j.jbusres.2007.01.001

Baker, W. E., \& Sinkula, J. M. (1999). The Synergistic Effect of Market Orientation and Learning Orientation On Organiza-tional Performance. Journal of the Academy of Marketing Science, 27(Fall), 411-427. doi: $10.1177 / 0092070399274002$

Bao, Y., Sheng, S., \& Zhou, K. Z. (2012). Network-based market knowledge and product innovativeness. Marketing Letters, 23(1), 309-324. doi:10.1007/s11002-011-9155-0

Bodlaj, M., Coenders, G., \& Zabkar, V. (2012). Responsive and Proactive Market Orientation and Inovation Succes Under Market And Technological Turbulence. Journal of Business Economic and Management, 13(4), 666-687.

Bodlaj, M., \& Rojsek, I. (2010). The Market Orientation of Slovenian Companies: Two-Group Comparisons. Economic and Business Review, 12(2), 89-108.

Bodlaj, M. (2010). The Impact of a Responsive and Proactive Market Orientation On Innovation and Business Performance. Economic and Business Review, 12(4), 241-261.

Bolton, R. N., Gustafsson, A., McColl-Kennedy, J. R., Sirianni, N. J., \& Tse, D. K. (2014). Small details that make big differences: A radical approach to consumption experience as a firm's differentiating strategy. Journal of Service Management, 25(2), 253-274.

Clark, B. H. (1999). Marketing Performance Measures: History and Interrelationships. Journal of Marketing Management, 15, 711-732.

Clark, B. H. (2000). Managerial Perceptions of Marketing Performance: Efficiency, Adaptability, Effectiveness, and Satisfaction. Journal of Strategic Marketing, 8, 3-25.

Covin, J. G., \& Slevin, D. P. (1989). Strategic management of small firms in hostile and benign environments. Strategic Management Journal, 10(1), 75-87.

Damarwulan, M. L., Farida, N., \& Andriyansah. (2018). The Role of Quality of Entrepreneurial Networking and Responsiveness to Global Business Environment in Improving the Marketing Performance of Indonesian Exporting SMEs. Quality - Access to Success, 7.

Day, G. S. (1994). The capabilities of market-driven organizations. Journal of Marketing, 58(October), 37-52.

Day, G. S. (2002). Managing the market learning process. Journal of Business and Industrial Marketing, 17(4), 2002.

Day, G. S., \& Nedungadi, P. (1994). Managerial representations of competitive advantage. Journal of Marketing, 58(2 (Apr)), 31-44.

Day, G. S., \& Wensley, R. (1988). Assessing Advantage: A Framework for Diagnosing Competitive Superiority. Journal of Marketing, 52(April), 1-20. 
Fang, S.-R., Chang, E., Ou, C.-C., \& Chou, C.-H. (2014). Internal market orientation, market capabilities and learning orientation. European Journal of Marketing, 48(1/2), 170-192.

Farida, N., Naryoso, A., \& Ardyan, E. (2017). Model of Relationship Marketing Partnership Between Batik SMEs and Batik Distributors in Central Java, Indonesia. International Journal of Social Ecology and Sustainable Development, 14.

Foley, A., \& Fahy, J. (2004). Towards a further understanding of the development of market orientation in the firm: A conceptual framework based on the market-sensing capability. Journal of Strategic Marketing, 12(December), 219-230.

Harmancioglu, N., Grinstein, A., \& Goldman, A. (2010). Innovation and Performance Outcomes of Market Collection Efforts: The Role of Top Management Team Involvement. International Journal of Research in Marketing, 27, 33-43.

Hart, S., Tzokas, N., \& Saren, M. (1999). The Effectiveness of Market Information in Enhancing New Product Success Rate. European Journal of Innovation Management, 2(1), 20-35.

Hidayanti, I., Herman, E. L., \& Farida, N. (2018). Enganging Customer Through Social Media to Improve Industrial Product Development: The Role of Customer Co-Creation Value. Journal of Relationship Marketing, 13.

Hoffman, D. L., \& Novak, T. P. (1996). Marketing in Hypermedia Computer-Mediated Environments: Conceptual Foundations. Journal of Marketing, 60(3), 50-68.

Hunt, S. D. (1995). The Resource-Advantage Theory of Competition: Toward Explaining Productivity and Economic Growth. Journal of Management Inquiry, 4(4), 317-332.

Hunt, S. D., \& Morgan, R. E. (1996). The Resource-Advantage Theory of Competition: Dynamics, Path Dependencies, and Evolutionary Dimensions. Journal of Marketing, 60(4 (oct)), 107-114.

Hunt, S. D., \& Morgan, R. M. (1997). Resource-Advantage Theory: A Snake Swallowing Its Tail or a General Theory of Competition. Journal of Marketing, 61(October), 74-82.

Jenny, D. (2005). Knowledge management, innovation and firm performance. Journal of Knowledge Management, 9, 101.

Jimenez-Jimenez, D., \& Sanz-Valle, R. (2011). Innovation, Organizational Learning, and Performance. Journal of Business Research, 64, 408-417.

Johnson, J. D. (2001). Success in Innovation Implementation. Journal of Communication Management (London), $5(4), 341-459$.

Kajalo, S., \& Lindblom, A. (2015). Market orientation, entrepreneurial orientation and business performance among small retailers. International Journal of Retail \& Distribution Management, 43(7), 580-596.

Khong, K. W., Theresa, J., \& Leong, W. S. (2010). Online advertising: A study on Malaysian consumers. International Journal of Business and Information, 5(2), 111-134.

Kok, R. A. W., Hillebrand, B., \& Biemans, W. G. (2003). What Makes Product Development Market Oriented? Towards a Conceptual Framework. International Journal of Innovation Management, 7(2), 137-162.

Lankinen, J., Rökman, M., \& Tuominen, P. (2007). Market-sensing capability and market orientation in the food industry: Empirical evidence from Finland. Paper presented at the 19 th Nordic Academy of Management Conference.

Li, Y.-H., Huang, J.-W., \& Tsai, M.-T. (2009). Entrepreneurial orientation and firm performance: The role of knowledge creation process. Industrial Marketing Management, 38(4), 440-449.

Mahmud, N., \& Hilmi, M. F. (2014). TQM and Malaysian SMEs Performance: The Mediating Roles of Organization Learning. Procedia-Social and Behavioral Sciences, 216-225(130).

Mauri, A., \& Minazzi, R. (2013). Web reviews influence on expectations and purchasing intentions of hotel potential customers. International Journal of Hospitality Management, 34(September), 99-107.

Meyer, C., \& Schwager, A. (2007). Understanding customer experience. Harvard Business Review, 85(2), $116-126$. 
Miller, D. (1983). The Correlates Of Entrepreneurship In Three Types Of Firms. Management Science, 29, 770-791.

Mochalova, A., \& Nanopoulos, A. (2014). A targeted approach to viral marketing. Electronic Commerce Research and Applications, 13(4), 283-294.

Morgan, N. A., Slotegraaf, J., \& Vorhies, D. W. (2009). Linking Marketing Capabilities With Profit Growth. International Journal of Research in Marketing, 26, 284-293.

Morgan, R. E., \& Berthon, P. (2008). Market Orientation, Generatif Learning, Innovation Strategy and Business Performance Inter-Relationship in Bioscience Firms. Journal of Management Studies, 45(8), 1329-1353.

Narver, J. C., \& Slater, S. F. (1990). The effect of a market orientation on business profitability. Journal of Marketing, 54(4), 20-35.

Narver, J. C., Slater, S. F., \& Maclachlan, D. L. (2004). Responsive and Proactive Market Orientation and NewProduct Success. Journal of Product Innovation Management, 21, 334-347.

Oh, J. C., Yoo, S. J., \& Park, B. I. (2012). A structural approach to examine the quality attributes of e-shopping malls using the Kano model. Asia Pacific Journal of Marketing and Logistics, 24(2), 305-327.

Olavarrieta, S., \& Friedmann, R. (2008). Market orientation, knowledge-related resources and firm performance. Journal of Business Research, 61(6), 623-630.

Roberts, N., \& Grover, V. (2012). Investigating Firm's Customer Agility and Firm Performance: The Importance of Aligning Sense and Respond Capabilities. Journal of Business Research, 65, 579-585.

See-To, E. W., \& Ho, K. K. (2014). Value co-creation and purchase intention in social network sites: The role of electronic word-of-mouth and trust: A theoretical analysis. Computers in Human Behavior, 31, 182-189.

Sussman, S. W., \& Siegel, W. S. (2003). Informational influence in organizations: An integrated approach to knowledge adoption. Information Systems Research, 14(1), 47-65.

Teece, D. J. (2007). Explicating dynamic capabilities: The nature and microfoundations of (sustainable) enterprise performance. Strategic Management Journal, 28, 1319-1350.

Tsai, K.-H., Chou, C., \& Kuo, J.-H. (2008). The Curvilinier Relationship Between responsive and Proactive Market Orientation and New Product Performance: A Contigent Link. Industrial Marketing Management, 37, 884-894.

Tseng, S.-M., \& Lee, P.-S. (2014). The effect of knowledge management capability and dynamic capability on organizanal performance. Journal of Enterprise Information Management, 27(2), 158-179.

Vargo, S. L., \& Lusch, R. F. (2008). Service-Dominant Logic: Continuing the Evolution. Journal of the Academy of Marketing Science, 36(1), 1-10.

Voola, R., \& O'cass, A. (2010). Implementing Competitive Strategies: The Role of Responsive and Proactive Market Orientations. European Journal of Marketing, 44(1/2), 245-266.

Wang, Y., Zeng, D., Benedetto, C. A., \& Song, M. (2013). Environmental Determinants of Responsive and Proactive Market Orientation. Journal of Business and Industrial Marketing, 28(7), 565-576.

Wang, Z. W., \& Wang, N. (2012). Knowledge sharing, innovation and firm performance. Expert Systems with Applications, 39(10), 3899-8908.

Wiklund, J., \& Shepherd, D. (2003). Knowledge-based resources, entrepreneurial orientation, and the performance of small and medium-sized businesses. Strategic Management Journal, 24(13), 1307-1314.

Wiklund, J., \& Shepherd, D. (2005). Entrepreneurial orientation and small business performance: A configuration approach. Journal of Business Venturing, 20(1), 71-91.

Zhang, J., \& Wu, W.-P. (2013). Social capital and new product development outcome: The mediating role of sensing capability in Chinese high-tech firms. Journal of World Business, 48, 539-548.

Zhang, Y., \& Zhang, X. e. (2012). The effect of entrepreneurial orientation on business performance: A role of network capabilities in China. Journal of Chinese Entrepreneurship, 4(2), 2012. 
Zomerdijk, L., \& Voss, C. (2009). Service design for experience-centric services. Journal of Service Research, 13, 67-82. 